\title{
Psalm 99: Die Here, ons God, is heilig
}

W S Prinsloo

Universiteit van Pretoria

Abstract

Psalm 99: The Lord, Our God, is holy

In this article there is a review of the research problems associated with Psalm 99, including the way in which the expression יהוה מלך should be understood. By way of a comprehensive exegetic approach involving attention to morphological, syntactic, stylistic and semantic details, there is an attempt to provide answers to the research problems. One of the points made is that Psalm 99 forms a cohesive artistic whole and that the expression ידרה מלך should be understood, not ingressively, but duratively.

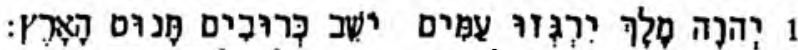
2

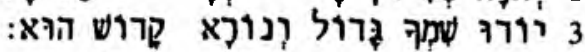
4a

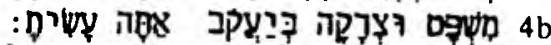

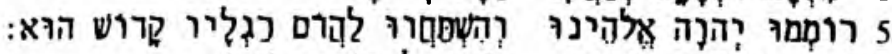
6a

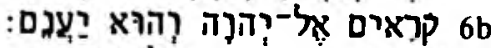

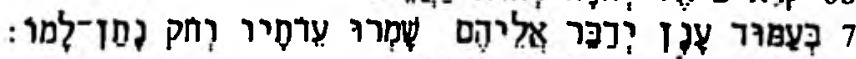
8a 8b

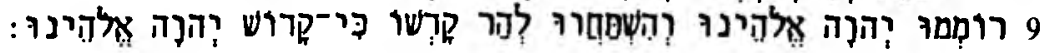




\section{INLEIDING}

In die navorsingsgeskiedenis van Psalm 991 in die besonder en dié van die sogenaamde koningspsalms in die algemeen, het 'n hele aantal probleme die toneel oorheers. Die belangrikste saak was en bly steeds die interpretasie van die uitdrukking

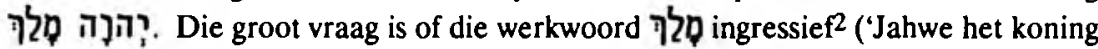
geword') of duratief ${ }^{3}$ ('Jahwe is koning/Jahwe heers as koning') verstaan moet word. Daar is selfs 'n standpunt dat bogenoemde twee moontlikhede nie teenoor mekaar staan nie, maar dat die ingressiewe en duratiewe betekenis met mekaar ver-

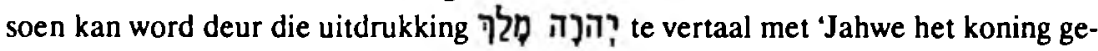
word en regeer nog steeds as koning'. 4 Sonder om die uitgebreide debat hier weer te gee, kan dit gesê word dat dit veral Sigmund Mowinckel $^{5}$ was wat die ingressiewe betekenis ('Jahwe het koning geword') voorgestaan het. Mowinckel huldig die hipotese dat daar in Israel 'n nuwejaarsfees in die herfs plaasgevind het waarop Jahwe se troonsbestyging as universele koning jaarliks gevier is. Hierdie fees is volgens Mowinckel gevier na analogie van die Babiloniese troonsbestygingsfees waarin Marduk die hoofrol gespeel het. 6

Aansluitend by bogenoemde probleem het die vraag na die Sitz im Leben van die Psalm ondersoekers ook besig gehou. Terwyl daar diegene was wat by Mowinckel aangesluit het, ${ }^{7}$ was daar egter ook eksegete wat ander Sitze im Leben gerekonstrueer het. ${ }^{8}$ Terwyl die meeste eksegete die Psalm eksilies/na-eksilies ${ }^{9}$ dateer, is daar tog ook diegene wat hulle uitspreek ten gunste van 'n voor-eksiliese ${ }^{10}$ datering.

Hoewel Psalm 99 normaalweg as die laaste van die sogenaamde troonsbestygingspsalms beskou word en Psalm 47, 93 en 96-99 tradisioneel tot die korpus gereken word, is daar egter geen eenstemmigheid in die navorsing oor watter Psalms tot dié kategorie gereken moet word nie. ${ }^{11}$

Nog ' $n$ vraag wat navorsers besig gehou het, was of Psalm 99 in besonder en die sogenaamde troonbestygingspsalms in die algemeen 'n Gattungsaanduiding is. Terwyl Mowinckel in terme van sy uitgangspunt nie anders kon as om van die troonsbestygingspsalms as Gattung ${ }^{12}$ te praat nie, is daar egter ook diegene wat eerder van Psalm 99 as 'n himne wil praat. 13

Die struktuur, indeling ${ }^{14}$ en Einheitlichkeit ${ }^{15}$ van die Psalm is ook belangrike sake van diskussie onder eksegete.

Uit die aard van die saak is dit onmoontlik om hier volledig aan al bogenoemde aspekte aandag te gee. Om dit te vermag, sou dit nodig wees om 'n hele monografie daaraan te wy. 16 Wat hier gepoog word, is om die Psalm op 'n teksimmanente manier te lees waarby aandag aan veral morfologiese, sintaktiese, stilistiese en semantiese aspekte gegee word. Sover moontlik word alle poëtiese konvensies dus in ag geneem. Hoewel Kittel die Psalm lank gelede reeds as 'Ein kunstvolles Gedicht' 
(Kittel 1922:322) beskryf het, ${ }^{17}$ het bogenoemde benadering nie genoeg aandag in die Forschungsgeschichte van die Psalm gekry nie. So 'n teksimmanente benadering sou ook lig kon werp op van die bogenoemde interpretasieprobleme.

\section{2. 'N ANALISE VAN Psalm 99}

Die Psalm kan in twee stansas verdeel word, naamlik vers 1-5 en vers 6-9. Hoewel die tweedeling hieronder nader gemotiveer word, is die basiese rede vir die tweedeling geleë in die refreinvers wat by vers 5 en vers 9 voorkom. Die eerste stansa (1-5) val uiteen in drie strofes, naamlik vers $1-3$, vers $4 a-4 b$ en vers 5 . Die tweede stansa bevat ook drie strofes, naamlik vers $6-7$, vers $8 a-8 b$ en vers 9 . Hierdie indeling van die Psalm kan soos volg gemotiveer word.

Die eerste strofe (1-3) se verbindinge kan soos volg omskryf word: vers 1 en vers 2 is baie nou aan mekaar verbind vanweë die feit dat albei die stiges deur ' $n$ vooropgeplaasde יזו ingelei word. Hierdeur word al die klem vanaf die begin van die gedig af reeds op Jahwe geplaas. Die bedoeling van die beklemtoning sou egter ook polemies kon wees, naamlik om te sê dat Jahwe koning is en geen ander God nie (cf Schmidt 1966:76-7718). Daar vind ook 'n opvallende woordherhaling tussen vers 1 en vers 2 plaas. Die עצ ('volke') wat in die eerste hemistige van vers 1 voorkom, word weer opgeneem in die tweede hemistige van vers 2 . Inhoudelik gaan dit in albei stiges oor die koningskap van Jahwe. Die eerste hemistige van vers 1 beskrywe die koningskap van Jahwe in internasionale terme ('volke') terwyl die tweede hemistige dit in kosmologiese terme ('aarde') doen. Die aarde wat 'bewe' is 'n metafoor om die reaksie van die volkere op die daadwerklike koningskap van Jahwe te beskryf. Vers 2 beskryf die koningskap van Jahwe in nasionale terme ('Sion') en gaan dan weer oor in internasionale terme ('volke'). Sion word hier gesien as die setel van Jahwe, die middelpunt vanwaar sy koningskap universeel uitkring.

Beide die stiges is parallel opgebou:

1 Die Here is koning, laat die volke bewe;

Hy troonoor die gerubs, laat die aarde wankel.

2 Die Here is groot in Sion.

en verhewe is Hy oor al die volke.

Die verskil tussen die twee stiges is egter dat daar in vers 2 nominale sinne voorkom teenoor die verbale sinne van vers 1 .

Hoewel die uitdrukking 'Hy troon (ישב) oor die kerubis' 19 elders in die Ou Testament oorwegend met die verbondsark verbind word (vgl 1 Sam 4:4; 2 Sam 6:2; 1 
Kron 13:6), moet dit hier in die lig van die koningsmetafoor, wat in hierdie twee stiges oorheers, gelees word. Dat Hy oor die 'kerubs' troon, beteken dus dat Jahwe koning van die hele aarde is. ${ }^{20}$ In die lig van hierdie en die hieropvolgende stiges blyk dit dus duidelik dat die uitdrukking יהוד מלך nie, soos Mowinckel betoog, wil sê dat en hoe Hy koning geword het nie, maar hoe Hy sy koningskap uitoefen (cf ook Michel 1956:65).

Vers 3 skakel nou met die voorafgaande vers 1-2. Die mees opvallende saak is dat die woord גרול ('groot') wat in vers 2 voorkom weer in vers 3 opgeneem word. In die eerste geval word dit vir die teenwoordigheid van Jahwe in Sion gebruik, terwyl dit in die tweede geval vir die naam van Jahwe gebruik word. Die feit dat twee

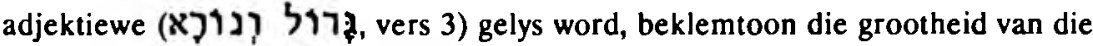
koningskap van Jahwe nog meer.

Jahwe word in vers 2 en vers 3 ook op parallelle wyse beskrywe:

\section{('Verhewe is Hy') הכד 2 3}

' $n$ Faktor wat vers 3 verder aan die voorafgaande vers $1-2$ - by name aan vers 1 bind, is die jussiewe vorme ('Laat die volke bewe,' vers 1; 'Laat die aarde wankel,' vers 1; 'Laat hulle U Naam loof,' vers 3 ). Die 'hulle' van vers 3 verwys vanselfsprekend na die 'volke' van vers 2 . Dit is ook opvallend dat aldrie stiges met ' $n$ jod begin. Al dié argumente stel die noue verhouding van vers 1-3 bo alle twyfel.

Vers 4a is die crux interpretum van die Psalm ${ }^{21}$. Sonder om hier al die verskillende standpunte en argumente te herhaal, sluit ek aan by die oplossing wat Scoralick (1989:67-68; cf ook Jeremias 1987:114; Michel 1960:220) bied, deur die vers soos volg te vertaal: 'En die sterkte van die Koning is dat Hy die reg liefhet.'

Dit is egter nie net die interpretasie van vers 4 wat probleme skep nie, maar ook die verhouding daarvan tot die res van die Psalm. Sommige eksegete wil byvoorbeeld ' $n$ heel nuwe gedeelte hier laat begin. Hoewel ek ook van oordeel is dat daar 'n nuwe strofe by vers 4 begin, het vers 4 tog 'n noue verbintenis met die voorafgaande. Eers egter ' $n$ woord oor die verhouding tussen vers $4 a$ en vers $4 b$. Die twee stiges is om verskeie redes sterk op mekaar aangewese: Die opvallendste is die voorkoms van die woord DפWp in vers $4 a$ en in vers $4 b$. Dit is ook die enigste plek in die Psalm waar dié woord voorkom. Bykomend hierby is die feit dat die twee stiges inhoudelik sterk by mekaar aansluit in die sin dat dit hier om die juridiese funksies (cf

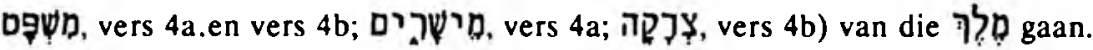
Jahwe word hier as die ideale koning geteken wat sorg dat reg en geregtigheid ge-

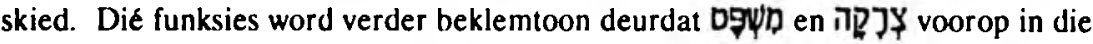
sinskonstruksie van vers $4 \mathrm{~b}$ geplaas word. Die noue verbintenis tussen vers $4 \mathrm{a}$ en 
vers $4 \mathrm{~b}$ kom verder daarin tot uiting deurdat die handeling van Jahwe op parallelle manier by wyse van ' $n$ werkwoord in die perfektumvorm en ' $n$ vooropgeplaasde persoonlike voornaamwoord in beide stiges beskryf word:

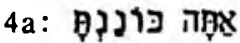

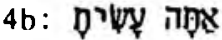

Vers 4 het egter ook 'n sterk verbintenis met die voorafgaande deel. Dit is opvallend dat die enigste waw-kopulatief 22 aan die begin van 'n stige juis by vers $4 a$ voorkom. Hierdeur word 'n doelbewuste band met die voorafgaande vers 3 bewerkstel-

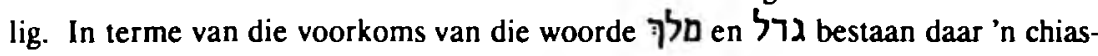
tiese relasie tussen vers 1 , vers 2 , vers 3 en vers $4 a$ :

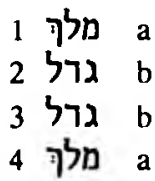

Hierdie chiasme beklemtoon uiteraard die koningskap en grootheid van Jahwe. Om van Jahwe op himniese wyse as die Sionsteologie en -tradisie (cf Scoralick 1989:54).

'n Kenmerk van vers 3 is dat daar afwisselend van Jahwe in die derdepersoon en met Hom in die tweedepersoon gepraat word. Vers 4 a vertoon dieselfde kenmerk. Uiteraard sluit vers 4 ook inhoudelik by die voorafgaande aan omdat dit in die vers nog steeds om die beskrywing van die Koning gaan. In een opsig sluit vers 4 egter ook by veral vers 6-8 aan: Hierdie verse adem, soos wat aangetoon sal word, 'n Israelities-partikularistiese gees. Die voorbrand hiervoor word egter reeds in vers 4 b gemaak waar daar van 'Jakob' gepraat word.

Om net weer saam te vat: vers $1-3$ vorm die eerste strofe en vers $4 a-4 b$ die tweede strofe, maar vers $4 \mathrm{a}$ is ook baie nou aan die voorafgaande verbind.

Vers 5 word van die voorafgaande onderskei deurdat dit met ' $n$ imperatief ingelei word en daar nou oor Jahwe in die derdepersoon gepraat word teenoor die einde van vers 4 waar daar in die tweedepersoon tot Jahwe gepraat word. Vers 5 vorm 'n strofe. Daar is egter verskeie kriteria op grond waarvan aangevoer kan word dat die Psalm in twee stansas, naamlik vers $1-5$ en vers 6-9, verdeel moet word en dat vers 5 die afsluiting van die eerste stansa is. Vers 5 en vers 9 vorm as refreine onderskeidelik die afsluiting van die eerste en die tweede stansa.

By vers $6 a$ begin daar ' $n$ nuwe stansa. By die bogenoemde redes kan daar ook nog gesê word dat vers $6 a$ van die voorafgaande onderskei kan word deurdat dié 
vers 'n histories/partikularistiese aard vertoon deur die verwysing na Moses, Aäron en Samuel. Tog is dit ook nie heeltemal 'n nuwe gedagte nie, want in vers $4 \mathrm{~b}$ word daar reeds van 2 ?, wat hier waarskynlik as Israel verstaan moet word, gepraat. In vers 6-8 word die algemene uitsprake van vers 4 en die voorafgaande stiges oor die koningskap van Jahwe by wyse van konkrete voorbeelde uit die geskiedenis toegelig en verduidelik (cf Schreiner 1963:202).

Om egter weer na vers 5 toe terug te keer: Die vers sou as 'n tristige omskryf kon word waarvan die eerste twee dele op 'n parallelle wyse opgebou is deurdat

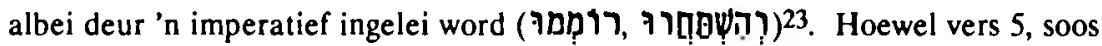
reeds aangetoon, 'n nuwe strofe vorm, het dit tog sterk verbintenis met die voorafgaande. Eerstens omdat die koningsmetafoor, wat so 'n belangrike plek in beide vers $1-3$ en vers $4 a-4 b$ inneem, weer hier in vers 5 ('die voetbank van sy voete') ${ }^{24}$ opgeneem word. Die imperatief רוממו ('verhoog...') gryp ongetwyfeld terug na ('Hy is verhewe...') in vers 3. Die woord שר שר moet as 'n Stichwort beskou word omdat dit nie net hier in vers 5 nie, maar ook elders in die Psalm voorkom (vgl vers 3 , vers 5 , vers 9 [x2]). Dit is eg:er opvallend dat dit slegs by vers 3 en hier in die derde deel van vers 5 in die spesifieke kombinasie van ('Hy is heilig') voorkom. Dié feit verhoog die noue verbintenis van vers 5 met die voorafgaande nog meer. As refreinvers is vers 5 egter ook nie sonder verbintenis met die tweede stansa nie. Dit is veral opvallend dat nog 'n Stichwort, אלקינר ('ons God'), wat nie minder as drie keer in die tweede stansa voorkom nie (vgl vers 8 , vers $9[2 x]$ ), ook hier in vers 5 gebruik word.

Soos reeds hierbo aangevoer, begin daar 'n nuwe stansa en vanselfsprekend 'n nuwe strofe by vers $6 \mathrm{a}$. Die twee hemistiges van vers $6 \mathrm{a}$ vertoon parallelle trekke:

Moses en Aäron was onder sy priesters

en Samuel onder dié wat sy Naam aangeroep het.

'n Opvallende kenmerk van vers 6 is die alliterasie wat betref die medeklinkers $\boldsymbol{D}$ en ש (שמו ,שמואל ,משה). Deur middel van die woord ('sy Naam') word daar 'n doelbewuste band met die vorige stansa (cf Jahwe nie weer direk in vers 6 genoem word nie, maar dat daar bloot van 'sy priesters' en 'sy Naam' gepraat word, dui ook daarop dat vers 6 vanselfsprekend terugverwys na die voorafgaande gedeelte.

Die gedeelte vers $6 \mathrm{a}-8 \mathrm{~b}$ vertoon een dominante kenmerk en dit is dat die derdepersoon meervoud suffiks - verwysende na 'Moses', 'Aäron' en 'Samuel' - veelvuldig voorkom ('Hy het hulle geantwoord', vers 6b; 'Hy het met hulle gepraat', vers 7; '...die insettinge wat Hy vir hulle gegee het', vers 7; 'U het hulle geantwoord', vers 8a; ' $U$ was 'n vergewende God vir hulle gewees', vers $8 \mathrm{~b}$; 'hulle dade', vers $8 \mathrm{~b}$ ). Die gedeelte vers $6 \mathrm{a}-8 \mathrm{~b}$ kan egter in twee strofes verdeel word, naamlik vers 6-7 en vers 
8a-b, veral op grond van die feit dat daar van Jahwe in die derdepersoon gepraat word in eersgenoemde gedeelte terwyl $\mathrm{Hy}$ in vers $8 \mathrm{a}-8 \mathrm{~b}$ direk in die tweedepersoon aangespreek word. Die verskil kom die duidelikste na vore by Dy? ה ה ('Hy het hulle geantwoord', vers 6b; cf ook 'sy priesters', 'sy Naam', vers 6a; 'sy insettinge',

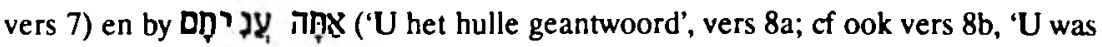
vir hulle 'n vergewende God').

Die stige-verhouding van vers $6 a-7$ en vers $8 a-8 b$ kan soos volg omskryf word. Beginnende met eersgenoemde strofe (6a-7) kan gesê word dat die drie stiges baie nou met mekaar skakel. Eerstens kan opgemerk word dat daar afstandsrym tussen vers $6 a(1)$ ( en vers 7 (ל ) bestaan. 'n Mens sou dit selfs as inclusio-rym, waardeur vers $6 \mathrm{a}-7$ as ' $n$ afgeronde geheel na vore tree, kon beskryf. Op inhoudelike vlak is die drie stiges ook op mekaar aangewese omdat dit hier - met uitsondering van die vermelding van Samuel - oor die Woestyn- en Sinaitradisie handel. Tussen vers $6 a$ en vers $6 b$ is daar ' $n$ anadiplotiese verhouding aangesien die stam $x$, wat aan die einde vers $6 a$ voorkom, weer aan die begin van vers $6 \mathrm{~b}$ opgeneem word. Hierdeur word daar uiteraard 'n sterk band tussen die twee stiges gelê. Vers $6 \mathrm{~b}$ vertoon 'n chiastiese opbou wat soos volg weergegee kan word:

Roependes tot Jahwe

Hy (Jahwe) het hulle geantwoord

Hierdie chiastiese struktuur laat die dialogiese verhouding tussen Jahwe en 'hulle' verwysende na Moses, Aäron en Samuel as verteenwoordigers van die volk van die Here - nog meer na vore tree.

Die verhouding van vers 7 met die direkvoorafgaande vers $6 \mathrm{~b}$ kan soos volg omskryf word: Soos die laaste gedeelte van vers $6 \mathrm{~b}$ ('Hy het hulle geantwoord'), is Jahwe die subjek van die werkwoord terwyl 'hulle' die objek is ('Hy het met hulle gepraat...'). Soos in vers $6 b$ (ענה) het ons in vers 7 'n werkwoord wat met praat te doen het (רבר). In terme van die elemente subjek/objek is daar 'n chiastiese verhouding tussen vers $6 \mathrm{~b}$ en vers 7 :

Roependes (is hulle) tot Jahwe en Hy het hulle geantwoord

Hy het met hulle gepraat en hulle het sy verordeninge bewaar

Hierdie chiastiese relasie tussen vers $6 \mathrm{a}$ en vers 7 beklemtoon, soos in die geval van vers $6 \mathrm{~b}$, die dialogiese verhouding tussen Jahwe en 'hulle'. Die uitdrukking רִּ ('in 'n wolkkolom') versterk die verhouding tussen vers 6 en vers 7 nog meer aangesien dit as 'n 'double-duty modifier' (cf Dahood 1986:369) beskou kan word wat sowel na vore as na agter funksioneer. 
Die tweede gedeelte van vers 7 is ook chiasties opgebou:

Hulle het bewaar sy verordeninge

en 'n insetting het Hy hulle gegee

Soos reeds aangetoon, lê die verbintenis van vers $8 \mathrm{a}$ en vers $8 \mathrm{~b}$ daarin dat daar van Jahwe in die tweedepersoon (' $U$ ') gepraat word. Vers $8 \mathrm{a}$ en vers $8 \mathrm{~b}$ vertoon eind-

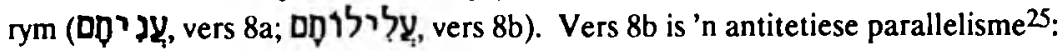

'n Vergewende God was $U$ vir hulle gewees//Maar 'n wreker oor hulle sondes

Hierdie antitetiese parallelisme bring albei fasette van Jahwe se koningskap na vore, naamlik dat Hy vergewe maar dat Hy ook straf (cf ook Brueggemann 1984: 149). Die toorn van Jahwe oor die sonde word verhoog deur die alliterasie in die

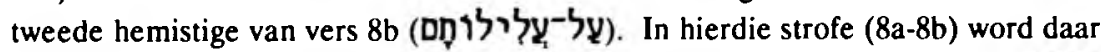
egter ook verbindinge met voorafgaande dele bewerkstellig. Die uitdrukking ?וה צור van vers 5 word hier weer opgeneem. Daar is reeds gewys op die ooreenkoms tussen 'Hy het hulle geantwoord' (6b) en 'U het hulle geantwoord' (8a). Deur laasgenoemde twee werkwoorde (D) 2 (wolk, vers 7) word daar alliterasie bewerk wat die noue verbintenis in vers 6-8 nog verder bevestig.

Vers 9, die laaste strofe van die tweede stansa, sluit die Psalm op 'n hoogte-punt af. Hierdie tristige se eerste twee elemente is parallel opgebou:

Verhoog Jahwe, ons God//buig julle neer voor sy heilige berg

Vers 9 is ' $n$ refrein op vers 5 en gryp dus terug daarheen, maar vertoon tog 'n beלברם כגליריו ('voor die voetbank van sy voete') in vers 5 het ons לקר קרוֹ ('voor sy heilige berg') in vers 9. Die uitdrukking in vers 5 moet in die lig van die koningsmetafoor van die eerste strofe verstaan word. Die uitdrukking in vers $\mathbf{9}$ kan egter nie anders as in die lig van die onmiddellike konteks, naamlik die Sinaitradisie verstaan word nie. Tog vertoon vers 9 as slot van die Psalm ook 'n 'ambiguity' in die sin dat die 7i] ('berg') nie net na Sinai (cf die Sinaitradisie in vers 7) hoef te verwys nie, maar dit kan ook na Sion ${ }^{26}$ (cf vers 2 ) verwys sodat ons tog ook weer die koningsmetafoor in vers 9 kan terugvind.

Dat vers 9 die hoogtepunt van die Psalm is en dat daar 'n doelbewuste Steigenung plaasvind, kan bespeur word bloot deur te kyk na die manier waarop die uitdrukking קרוש הוא ('Hy is heilig') gebruik word (cf Scoralick 1989:48): In vers 3 kom die uitdrukking voor as deel van 'n jussief ('laat...') dat die volkere die 'Naam' van Jahwe moet loof. In vers 5 word dit nog meer gekonsentreerd gebruik as deel 
van ' $n$ imperatief om die versamelde godsvolk tot aanbidding op te roep en word Jahwe pertinent as 'ons God' aangedui. In vers 9, wat as refrein op vers 5 voorkom, word die motivering tot lof en aanbidding nog sterker gemotiveer deur die uitdrukking 'Heilig is Hy'. Vers 9 vertoon, wat nog 'n belangrike aspek betref, 'n progressie

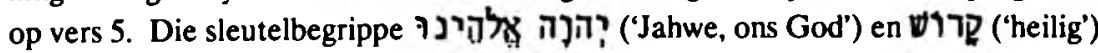
wat onderskeidelik slegs een keer in vers 5 voorkom, kom elk twee keer in vers 9 voor. Om die waarheid te sê, dié begrippe wat in vers 5 apart van mekaar voorkom,

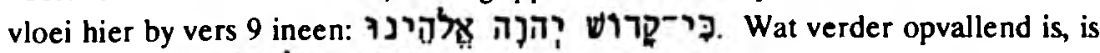

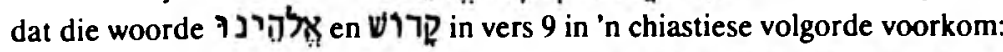

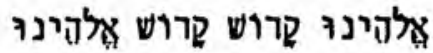

Al hierdie stylfigure kombineer die 'heiligheid' en die feit dat Jahwe 'ons God' is op 'n treffende wyse. Dat Jahwe heilig is, beteken dus in terme van Psalm 99 dat Hy 'ons God' is - dat Hy by sy volk is. Hierdie feit word as grond en motivering gebruik

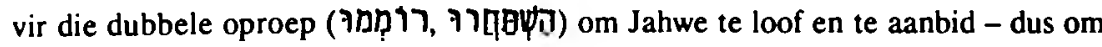
Hom as koning te aanvaar. Uit die voorafgaande opmerkings vloei logies voort dat vers 9 langer as die eerste refrein (5) is. Dit gebeur dikwels in die Hebreeuse poēsie dat die finale refrein langer as die voorafgaande refreine is (Watson 1986:297) om sodoende die gedig tot 'n hoogtepunt te voer. Dit is presies wat hier in Psalm 99 gebeur, naamlik dat die laaste vers die hele Psalm saamvat en tot 'n hoogtepunt voer.

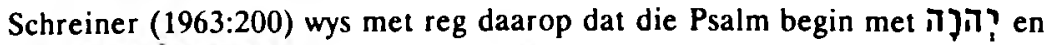

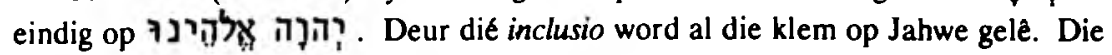
stylfiguur, asook die feit dat die naam en die handeling van Jahwe konstant deur die Psalm voorkom, gee ons die reg om van die Psalm te praat as 'n Jahwe-sentriese Psalm.

\section{SAMEVATTENDE OPMERKINGS}

Die analise van Psalm 99 bevestig dat ons te doen het met 'n gedig waar daar van allerlei poëtiese tegnieke gebruik gemaak word. Die resultaat is 'n samehangende, kunstige gedig. Vers 1-3 konsentreer op die koningskap van Jahwe wat in Sion gesetel is, maar wat universeel uitkring oor die hele aarde. Jahwe word as die ideale koning (4-5) geteken wat reg en geregtigheid uitoefen en wat alles reg-maak. So 'n koning moet verhef en geprys word. Voor so 'n koning moet 'n mens laag in aanbidding neerbuig. Die hele konteks van die Psalm dui daarop dat die koningskap van Jahwe nie ingressief verstaan moet word nie, maar wel duratief: Jahwe is koning en Hy bly koning. Vir Mowinckel se hipotese van 'n troonsbestygingsfees en die ingressiewe betekenis van die uitdrukking יהרה מלך kan daar geen gronde in die Psalm 
gevind word nie. Jahwe se koningskap het ook en veral in die heilsgeskiedenis (woestyntog, en Sinai) van sy volk tot uiting gekom. Dwarsdeur dié geskiedenis het Hy in 'n gespreksverhouding, 'n dialogiese verhouding, met sy volk gestaan sodat daar inderdaad van 'ons God' gepraat kan word. Die heiligheid van Jahwe en die feit dat Hy 'ons' God is, sluit mekaar egter nie uit nie, maar is albei deel van sy koningskap. Die feit dat Hy die vergewende God is, sluit ook nie uit dat Hy die God is wat die sonde straf nie. Die Psalm kan nie vasgevang word in 'n bepaalde Gattung nie. Tog kan gesê word dat die Psalm sekere himniese trekke vertoon en dat die basiese retoriese funksie van die Psalm daarin lê om die leser/hoorder te oortuig dat Jahwe koning is en dat alle lof Hom toekom. Hoewel daar geen direkte aanduidings in die Psalm is om dit te dateer nie, bestaan die vermoede dat dit 'n naeksiliese Psalm is, met ander woorde in die tyd toe die monargie nie meer bestaan het nie. Indien dit die geval sou wees, verklaar dit die feit waarom die koningskap van Jahwe so beklemtoon word in Psalm 99: Ten spyte van die ballingskap en ten spyte daarvan dat die monargie nie meer bestaan nie, is Jahwe nog Koning. In die opsig sou die Psalm dan ook 'n vertroostende funksie hê.

\section{Eindnotas}

1. Vir ' $n$ volledige oorsig oor die navorsingsgeskiedenis van die Psalm, kyk Scoralick (1989:9-16).

2. Vergelyk byvoorbeeld Gunkel (1926:429); Oesterley (1939:428); Day (1990:79. $80)$.

3. Vergelyk byvoorbeeld Eißfeldt (1928:101); Ridderbos (1954:88); Ridderbos (1958:454); Schreiner (1963:200); Schmidt (1966:76-79); Kraus (1966:682); Dahood (1986:367); Scoralick (1989:44, 51).

4. Kapelrud (1963:229-231) verteenwoordig dié standpunt. Ulrichsen (1977:373374) sluit hierby aan wanneer hy sê dat die teenstelling duratief/ingressief nie opgaan nie omdat Hebreeuse werkwoorde dikwels beide elemente bevat. Dit geld ook van die יהוה מלך-formule. Ulrichsen (1977:374) meen dat die ingressiewe moment van die werkwoord nie ingressief is in die sin van 'n begin asof Jahwe nou begin regeer nadat $\mathrm{Hy}$ byvoorbeeld 'n ander god onttroon het nie ('Die Vorstellung eines Götterkampfes is den Texten völlig fremd'). Aan die ander kant moet die duratiewe moment nie staties verstaan word asof Jahwe slegs die titel van koning dra nie, maar so dat Hy die koningsheerskappy uitoefen en Homself as koning bewys (Ulrichsen 1977:374). 
5. Vergelyk byvoorbeeld Mowinckel (1966:6). Vergelyk verder Mowinckel (1962) en (1966) waar hy 'n breedvoerige uiteensetting van sy hipotese en standpunte oor die troonsbestygingsfees en -psalms gee.

6. Vir 'n volledige uiteensetting en kritiese evaluasie van die hipotese van Mowinckel, vergelyk Michel (1956:40-68); Prinsloo (1969), Welten (1982:297-310). Kyk ook König (1927:231) wat hom teen dié hipotese uitspreek.

7. Vergelyk byvoorbeeld $\mathrm{H}$ Schmidt (1927).

8. Deissler (1979:387) is van mening dat die Psalm baie goed by die rite van die Loofhuttefees sou ingepas het. Weiser (1965:617, 641; cf ook Anderson 1981: 693) is van mening dat die troonsbestyging van Jahwe, waarvan hierdie Psalm en ander psalms ' $n$ refleksie sou wees, een van die ritus was wat 'n onderdeel van die jaarlikse Verbondsfees uitgemaak het.

9. Byvoorbeeld Van der Ploeg (1974:161); Deissler (1979:387); Jeremias (1987: 120); Loretz (1988:370). Duhm (1899:236) dateer dit selfs in die Makkabeërtyd.

10. Vergelyk byvoorbeeld Mowinckel (1962:117); Kraus (1966:682-683); Anderson (1981:694); Day (1990:73); Tate (1990:505-506). Kittel (1922:322) dink dat die digter midde in die profetiese tyd gestaan het en verbind dit aan die wonderbaarlike redding van Jerusalem in die tyd van Sanherib.

11. Vergelyk Watts (1965:341-348) vir 'n oorsig oor dié deel van die debat.

12. Mowinckel (1962:106-192) praat van 'Psalms at the enthronement festival of Yahweh'. Gunkel \& Begrich (1933:94) praat ook van die 'Lieder von Jahves Thronbesteigung' en beskou dit as 'n 'kleine Gattung', 'n sub-Gattung, tot die himne. Gunkel verstaan dié Psalms - dus ook Psalm 99 - egter as eskatologiese liedere (cf Gunkel 1926:430; 1933:94-116). Deissler (1979:388) lê ook klem op die eskatologiese karakter van Psalm 99. Vergelyk Michel (1956:66) wat hom uitspreek teen 'n eskatologiese interpretasie van Psalm 99. Westermann (1977:114) is van mening dat daar nie van so iets as 'n Gartung van troonsbestygingspsalms gepraat moet word nie.

13. Kraus (1966:682) presiseer Psalm 99 as behorende tot die 'Jahwe-Königs-Hymnen' (cf ook Deissler 1979:387; Zenger 1986:186). Kittel (1922:322) praat van die Psalm as 'ein Hymnus'. Crüsemann (1969:70 voetnoot 6) beskou Psalm 99 _ saam met Psalm 93 en Psalm 97 - as 'ein ganz eigener Typ des Hymnus' wat gekenmerk word deur die inleidende יהוה מלך-roep en die afwisseling van die ' $U$ ' en 'Hy' styl. In aansluiting by Westermann praat Tate (1990:528) van die Psalm as 'n 'hymn of descriptive praise'. Schmidt (1966:74) meen dat die sogenaamde troonsbestygingspsalms geen afsonderlike, eenvormige Gattung uitmaak nie, maar dat dit himnes is met bepaalde inhoudelike gemeenskaplikhede. 
14. Terwyl daar diegene is wat 'n tweeledige indeling kies (naamlik vers 1.5 en vers 6-9, cf bv Boehmer 1906:156-158; Gunkel 1926:429; Kissane 1954:132; Van der Ploeg 1974:161; Anderson 1981: $694 \mathrm{ev;} \mathrm{Tate} \mathrm{1990:528),} \mathrm{is} \mathrm{daar} \mathrm{ook} \mathrm{eksegete}$ wat die Psalm in drie dele verdeel (naamlik vers 1-3, vers 4-5 en vers 6-9; cf bv Kirkpatrick 1903:584; Schreiner 1963:199-202; Weiser 1965:640 ev; Dahood 1986:368; Jeremias 1987:114-121; Scoralick 1989:56 ev), veral op grond van die drieledige קרוֹ הרוש in vers 3, vers 5 en vers 9. Dit lyk of Kraus (1966:683684) vir' $n$ vierledige indeling (1-3, vers 4 , vers 5 en vers 6-9) kies.

15. Loretz (1988:370) praat byvoorbeeld van 'Das patch-work des Textes', aangesien die teks volgens hom 'n groei- en interpretasieproses deurloop het. Hy identifiseer 'n klomp latere redaksionele byvoeginge op grond van sy kolometriese analise (cf Loretz 1988:364-368). Jeremias (1987:119) identifiseer die tweede deel van vers 7 en vers $8 \mathrm{~b}$ as latere redaksionele byvoegings omdat dié dele volgens hom sowel inhoudelik as formeel nie mooi inpas nie. Westermann (1977:113) sê van die Psalm: 'im übrigen ist dieser Psalm in seiner Komposition schwer zu verstehen und wahrscheinlich auch nicht in der ursprünglichen Ordnung erhalten.' Hy is van mening dat vers $5-9$, wat hy as 'n afgeronde lofpsalm sien, slegs sekondèr met vers $1-4$ verbind is. Buttenwieser (1938:363) is weer van oordeel dat vers 6-8 so verskil van die res van Psalm 99 dat dit nie oorspronklik deel van die Psalm kan wees nie, maar dat dit eerder 'n fragment van ' $n$ ander Psalm is. Ook Briggs \& Briggs (1909:309) meen dat vers 6-9 deur 'n latere redaktor, wat meer partikularisties was, bygevoeg is. Gunkel (1926:428431 ) is nie te vrede met die volgorde van die verse soos wat hulle tans in die Masoretiese Teks voorkom nie, maar bring ' $n$ herrangskikking teweeg deur byvoorbeeld vers 8 a voor vers 7 in te skuif.

16. Vergelyk Scoralik (1989) wat inderdaad 'n monografie op Psalm 99 geskryf het.

17. Scoralick (1989:58, cf ook 113) huldig ook so 'n standpunt: 'Die Psalm ist... stilistisch durchgängig geprägt und weist einen umfassende planmäBigen Aufbau auf.' Hierteenoor spreek Boehmer (1906:157) hom uit teen die standpunt dat die Psalm 'n kunsvolle gedig sou wees.

18. Vergelyk ook Köhler (1953:188-189) wat oor dié uitdrukking opmerk: 'Der Satz bedeutet: "Es ist Jahwä und nicht ein anderer Gott...der König ist".'

19. Vir 'n volledige bespreking van die woord ברוךרים, kyk Freedman \& O'Connor (1982:322-334); Zenger (1986:178).

20. Vergelyk Gunkel (1926:429) wat met reg opmerk: 'Der Keruben-Thron ist im Zusammenhange des Psalms der höchste Thron der Welt: "er hat sich auf die Keruben gesetzt" heißt: er ist König der ganzen Erde geworden.' 
21. Vir 'n omskrywing van die probleem en vir 'n opgawe van die belangrikste oplossings vir die probleem, kyk Scoralik (1989:62-68). Vergelyk ook die belangrikste kommentare ad hoc waar allerlei tekskritiese veranderinge voorgestel word in 'n poging om die interpretasieprobleem op te los. Vergelyk ook Eaton (1968:555-556) in dié verband.

22. Jeremias (1987:114), wat 'n breuk by vers 4 bemerk, beskou die waw egter as antiteties en vertaal dit met 'aber'.

23. Vergelyk Kreuzer (1985:39-60) vir 'n volledige bespreking van die betekenis en voorkoms van השחרור. Uit dié bespreking blyk ook duidelik dat die koningsmetafoor 'n belangrike bestandeel van die betekenis van die werkwoord uitmaak.

24. Duhm (1899:235; cf ook Scoralick 1989:43) is van mening dat dié uitdrukking na die tempelberg verwys. Weiser (1965:642) sluit hierby aan, maar hy sê dat dit selfs na die hele aarde kan verwys. Mettinger (1982:23) en Tate (1990:529) is byvoorbeeld van mening dat dit na die ark as 'voetstoel' van Jahwe verwys. Kirkpatrick (1903:585) wys die moontlikheid van die ark af omdat daar geen ark in die tweede tempel was nie. Mowinckel (1962:117) dink weer dat die uitdrukking na die ark verwys en gebruik dit as 'n motivering om die Psalm voor-eksilies te dateer. Wat die presiese betekenis van dié uitdrukking ook mag wees, uit die konteks is dit tog duidelik dat dit hier in verband met die konigsmetafoor gelees moet word.

25. Sowel Whybray (1969:237-239) as Whitley (1973:227-230) probeer die vergeldende, toornige handeling van Jahwe teenoor sy volk, soos wat dit in die tweede deel van die stige beskryf word, versag. Whybray doen dit deur die suffiks van סול על מל nie as 'n subjektiewe genitief nie ('hulle sondes', $d$ w s die sonde wat hulle gepleeg het), maar as 'n objektiewe genitief ( $d$ w s die sondes wat teenoor hulle gepleeg is) te interpreteer. Whitley probeer dit bewerkstellig deur 'n teks-

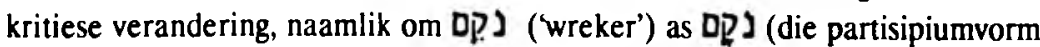
van נק נ, 'vergewe,' 'reinig') te vokaliseer. Daar bestaan egter geen rede om enige een van die voorstelle te aanvaar nie. Die Sinai- en Woestyntradisie, wat hier die onmiddellike konteks vorm, is tog ook getuienis daarvan dat Jahwe sy toorn teenoor sy ongehoorsame volk laat geld het. Dat Jahwe as 3 (vers 3, 'verskriklik') aangedui word, beteken tog dat Hy ook toornig kan optree. Vers $8 \mathrm{~b}$ vertoon ook groot ooreenkomste met Eksodus 34:6.

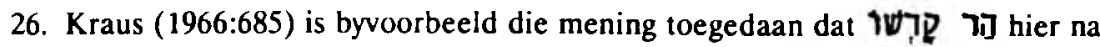
Sion verwys. 


\section{Literatuurverwysings}

Anderson, A A 1981. Psalms (73-150). 2nd ed. Grand Rapids: Eerdmans. (NeCBC).

Boehmer, J 1906. Zu Psalm 99. ZAW 26, 156-158.

Briggs, C A \& Briggs, E G 1909. The book of Psalms II. Edinburgh: Clark.

Brueggemann, W 1984. The message of the Psalms. Minneapolis: Augsburg Publishing House.

Buttenwieser, M 1938. The Psalms. Chicago/Illinois: The University of Chicago Press.

Crüsemann, F 1969. Studien zur Formgeschichte von Hymnus und Danklied in Israel.

Neukirchen-Vluyn: Neukirchener Verlag. (WMANT 32.)

Dahood, M 1986. Psalms II. New York: Doubleday. (AncB.)

Day, J 1990. Psalms. Sheffield: JSOT Press.

Deissler, A 1979. Die Psalmen. 2.Aufl. Düsseldorf: Patmos.

Duhm, B 1899. Die Psalmen. Freiburg: Mohr. (KHC 14.)

Eaton, J H 1968. Proposals in Psalms xcix and cxix. VT 18, 555-558.

Eißfeldt, $O$ 1928. Jahwe als König. $Z A W 46,81-105$.

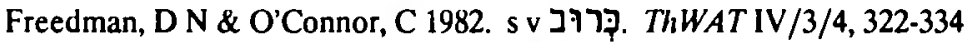

Gunkel, H 1926. Die Psalmen. 4.Aufl. Göttingen: Vandenhoeck \& Ruprecht. (HK 11/2.)

Gunkel, H \& Begrich, J. Einleitung in die Psalmen: Die Gattung der religiösen Lyrik Israels. Göttingen: Vandenhoeck \& Ruprecht. (HKAT 2.)

Jeremias, J 1987. Das Königtum Gottes in den Psalmen: Israels Begegnung mit dem kanaanäischen Mythos in den Jahwe-König-Psalmen. Göttingen: Vandenhoeck \& Ruprecht. (FRLANT 141.)

Kapelrud, A S 1963. Nochmals Jahwä malak. VT 13, 229-231.

Kirkpatrick, A F 1903. The book of Psalms. Cambridge: Cambridge University Press.

Kissane, E 1954. The book of Psalms II. Dublin: Browne \& Nolan.

Kittel, R 1922. Die Psalmen. 4.Aufl. Leipzig: Deichertsche Verlagsbuchhandlung. (KAT 14.)

Koehler, L 1953. Jahwäh malak. VT 3, 188-189.

König, E 1927. Die Psalmen. Gütersloh: Bertelsmann.

Kraus, H-J 1966. Psalmen 2 Teilband. 3.unver Aufl. Neukirchen: Neukirchener Verlag. (BKAT 15/2.)

Kreuzer, S 1985. Zur Bedeutung und Etymologie von hi¥ta aw h/yłt wy. VT 35, 39-60. 
Loretz, O 1988. Ugarit-Texte und Thronbesteigungspsalmen: Die Metamorphose des Regenspenders Baal-Jahwe. Münster: Ugarit-Verlag. (Ugaritisch-Biblische Literatur 7.)

Mettinger, T N D 1982. The dethronement of Sabaoth: Studies in the shem and kabod theologies. Gleerup: CWK.

Michel, D 1956. Studien zu den sogenannten Thronbesteigungspsalmen. VT 6, 4068.

... D 1960. Tempora und Satzstellung in den Psalmen. Bonn: Bouvier. (AET 1.)

Mowinckel, S 1962. The Psalms in Israel's worship I. Transl by D R Ap-Thomas. Oxford: Basil Blackwell.

... S 1966. Psalmenstudien II: Das Thronbesteigungsfest Jahwäs und der Ursprung der Eschatologie. Amsterdam: Schippers.

Oesterley, W O E 1939. The Psalms II. London: SPCK.

Prinsloo, W S 1969. Die sogenaamde troonsbestygingsfees in Israel. Proponentskripsie, Universiteit van Pretoria.

Ridderbos, J 1954. Jahwäh malak. VT 14, 87-89.

... 1958. De Psalmen II. Kampen: Kok. (COT.)

Schmidt, H 1927. Die Thronfahrt Jalıwes. Tübingen: Mohr.

Schmidt, W H 1966. Königtum Gottes in Ugarit und Israel: Zur Herkunft der Königsprädikation Jahwes. 2.Aufl. Berlin: Alfred Töpelmann. (BZAW 80.)

Schreiner, J 1963. Sion-Jerusalem. Jahwes Königssitz: Theologie der Heiligen Stadt im Alten Testament. München: Kösel-Verlag. (StANT 7.)

Scoralik, R 1989. Trishagion und Gottesherrschaft: Psalm 99 als Neuinterpretation von Tora und Propheten. Stuttgart: Katholisches Bibelwerk. (SBS 138.)

Tate, M E 1990. Psalms 51-100. Dallas: Word Books. (Word Biblical Commentary).

Ulrichsen, J H 1977. Jhwh malak: Einige sprachliche Beobachtungen. VT 27, 361374.

Van der Ploeg, J P M 1974. Psalmen II. Roermond: Romen \& Zonen. (BOT 7b).

Watson, W G E 1986. Classical Hebrew poetry: A guide to its techniques. 2nd ed.

Sheffield: The Uniity of Sheffield Press. (JSOT SS 26.)

Watts, J D W 1965. Jahweh malak Psalms. ThZ 21, 341-348.

Weiser, A 1965. The Psalms. Transl by H Hartwell. 3rd impr. London: SCM. (OTL.)

Welten, P 1982. Königsherrschaft Jahwes und Thronbesteigung. $V T$ 32, 297-310.

Westermann, C 1977. Lob und Klage in den Psalmen. 5.Aufl. Göttingen: Vandenhoeck \& Ruprecht.

Whitley, C F 1973. Psalm 99. ZAW 85, 227-230. 
Whybray, R N 1969. 'Their wrong doings' in Psalm 99. ZAW 81, 237-239.

Zenger, E 1986. Herrschaft Gottes/Reich Gottes II: Altes Testament. TRE 15, 176-189. 